\title{
OIL PRODUCTION AND HOST COMMUNITY RELATIONS IN NIGERIA: THE LIMITS OF THE UTILITARIAN APPROACH
}

\author{
Lola Ayotunde*
}

\begin{abstract}
While resource extraction generates enormous revenue for resource-rich countries such as Nigeria, it could also engender human rights violations in host communities. This article explores the efficacy of the prevailing utilitarian approach to oil and gas management in Nigeria. The utilitarian calculus is applied to Nigeria's oil and gas management to demonstrate how the utilitarian theory substantially influences the decisions of the Nigerian government. Although utilitarianism posits that the happiness of the majority is the primary objective of governance, this is arguably not a viable reason to violate the rights of the minority Niger Delta communities for the economic gains of the majority of Nigerians. As an alternative to the ineffective and unsustainable utilitarian resource management approach, this article discusses the importance of the human rights-based approach to resource management.
\end{abstract}

Keywords: Utilitarianism, Oil and Gas, Niger Delta, Human Rights, Corporate Social Responsibility.

DOI: https://dx.doi.org/10.4314/jsdlp.v9i2.8

* PhD student at the College of Law, University of Saskatchewan, Canada. She holds a master's (LL.M) degree in Sustainable Development Law from the same University and was called to the Nigerian Bar in 2012. The author is a member of the Law and Society Association and student member of the Saskatchewan Law Society. 


\section{INTRODUCTION}

This article examines the efficacy and sustainability of a utilitarian management approach to resource governance in Nigeria. Considering the importance of oil revenue to the Nigerian government, oil companies and the Nigerian people, the article explores whether, and to what extent, it remains legally justifiable to adopt utilitarian notions of right and wrong to formulate oil and gas policies in Nigeria's Niger Delta communities. ${ }^{1}$

Utilitarianism is a normative ethical theory, which hinges the rightness or wrongness of an action on the resultant consequences of that action. ${ }^{2}$ As a normative theory which promotes the consideration of the interest of others in decision making, the principles of the utilitarian theory influences core decision making processes, including governmental and organizational decision-making processes. ${ }^{3}$ Utilitarianism as a legal theory posits that man is motivated by the desire to be happy and that the primary goal of governance is to seek the greatest happiness of the greatest number of its people. ${ }^{4}$ An exploration of Nigeria's oil and gas management in light of the utilitarian principles reveals that the utilitarian theory fundamentally influences the Nigerian government's decision making processes. An analysis of the effects of the Nigerian government's decisions in oil and gas management, which are influenced by the utilitarian dictates, on the host communities brings to bear the challenges besetting the Niger Delta communities. This article aims to demonstrate that the Nigerian oil and gas management is utilitarian in nature. It also tries to explore the effectiveness or otherwise of the utilitarian theory in protecting the human rights of the Niger Delta peoples in Nigeria's oil and gas management, and establish that sustainable resource management and respect for human rights standards are more desirable than protecting

1 Jeremy Bentham, A Fragment on Government (Mews-Gate 1776) 1-5.

2 Robert Cavalier, "Online Guide to Ethics and Moral Philosophy: Utilitarian theories" (2002) <http://caae.phil.cmu.edu/Cavalier/80130/part2/ sect9.html> accessed 14 September 2017.

3 Shannon Bowen, "Organizational Factors Encouraging Ethical Decision Making: An Exploration into the Case of an Exemplar" [2004] 52:4 J. of Business Ethics 311; Michael Rockler, "Presidential Decision-Making: Utilitarianism vs Duty Ethics" (2007) < https://philosophynow.org/issues/64/Presidential_DecisionMaking_Utilitarianism_vs_Duty_Ethics $>$ accessed 2 March 2018.

4 Jeremy Bentham, A Fragment on Government (Mews-Gate 1776). 
the happiness of the majority to the detriment of the minority Niger Delta communities.

Nigeria's oil wealth is embedded mostly in the South-South region of the country also known as the Niger Delta region. For the purpose of this article, the oil-producing host communities in Nigeria will be collectively referred to as the Niger Delta. Although oil has also been discovered in Lagos State, commercial production and its effect on the host communities in Lagos is quite minimal, ${ }^{5}$ hence Lagos State is not considered an oil-producing state in this article. Despite Nigeria's abundant oil wealth and position as a leading oil and gas exporter in the world, the Niger Delta communities remain some of the poorest in the world. ${ }^{6}$ With a life expectancy of less than 47 years, a modest household income of US $\$ 1$ a day, and the lack of access to clean water due to oil spills, ${ }^{7}$ the Niger Delta region of Nigeria is a classic practical example of the resource curse. ${ }^{8}$

This article demonstrates the urgent need to transcend the utilitarian construct to resource governance in Nigeria to Human Rights Based Approach (HRBA). An HRBA will require the Nigerian government to ensure that oil resource extraction projects proceed in a manner that respects, protects and fulfils the fundamental human rights of the Niger Delta people. The HRBA to resource governance will also include a human right impact assessment threshold that would require governments and project proponents to demonstrate that human rights

5 Udeme Akpan, "Ranking of Lagos as Oil, Gas Producer to Improve in 2020" Vanguard (Lagos, 30 August 2017); Nigerian National Petroleum Corporation, "NNPC/CSECC, Lagos State Commence Exploration Activities of Greenfield Refinery...Says Refinery Will Produce 500,000 Liquefied Petroleum Gas" NNPC News \& Updates (Abuja, July 2012).

6 United Nations Development Programme, "Niger Delta Human Development Report" (UNDP Report, 2006)1, 131; Joseph C. Ebegbulem, Dickson Ekpe \& Theophilus Oyime Adejumo, "Oil Exploration and Poverty in the Niger Delta Region of Nigeria: A Critical Analysis" [2013] 4:3 Intl J of Business \& Social Science 279.

7 See UNICEF, “At a Glance: Nigeria" (2013) Statistics Report < https:// www.unicef.org/infobycountry/nigeria.html> accessed 17 November 2017.

8 Xavier Sala-i-Martin \& Arvind Subramanian, "Addressing the Natural Resource Curse: An Illustration from Nigeria" [2003] 22:4 J of African Economies 570; Annegret Mahler, "Nigeria: A Prime Example of the Resource Curse? Revisiting the Oil-Violence Link in the Niger Delta" [2010] German Institute of Global and Area Studies 25; Frederick van der Ploeg, "Natural Resources: Curse or Blessing?" [2011] 49:2 Journal of Economic Literature 366. 
standards have been complied with and are guaranteed to citizens in project planning and execution. ${ }^{9}$ Under this threshold, energy expansion projects are screened to ensure that projects, which could violate the human rights of the community, are not approved to proceed.

This article is divided into five sections. After this introduction, section 2 discusses the meaning, nature and scope of the utilitarian construct to resource governance. Section 3 unpacks the practical limitation and shortcomings of the application of the utilitarian approach to resource governance in Nigeria. Section 4 discusses the need for an HRBA to resource governance in Nigeria and offers practical insights on how the HRBA can be mainstreamed into resource governance in Nigeria. Section 5 is the conclusion.

\section{THE UTILITARIAN THEORY AND RESOURCE MANAGEMENT}

Utilitarianism is an ethical and legal theory which postulates that the proper course of action is that which maximizes satisfaction/happiness and minimizes negativity or suffering. It is an economic study that focuses on human behaviour and has a moral foundation. ${ }^{10}$ Bentham says, "it is the greatest happiness of the greatest number that is the measure of right and wrong", which he calls a fundamental axiom, ${ }^{11}$ adding that the tendency of an object or action to increase or decrease overall happiness is a utility. Classic utilitarianism is considered a form of consequentialism. Utilitarianism posits that "the moral worth of an action is determined only by its resulting consequences. However, there is debate over how much consideration should be given to actual

9 For detailed discussions of these debates, see Damilola Olawuyi, The Human Rights-Based Approach to Carbon Finance (Cambridge University Press 2016) 1-20. See also Oyeniyi Abe, "The Feasibility of Implementing the United Nations Guiding Principles on Business and Human Rights in the Extractive Industry in Nigeria" [2016] Afe Babalola University Journal of Sustainable Development Law \& Policy 151-154; United Nations Environment Programme, Climate Change and Human Rights (UNEP 2015) 5-25.

10 Eban Goodstein, Economics and the Environment (6th edn, John Wiley 2011) 26.

11 Jeremy Bentham, A Fragment on Government (Mews-Gate 1776). 
consequences, foreseen consequences and intended consequences". ${ }^{12}$

Bentham defines the Principle of Utility as "the principle which approves or disapproves of every action whatsoever, according to the tendency which it appears to have to augment or diminish the happiness of the party whose interest is in question". ${ }^{13}$ This definition of utility applies to the actions of individuals and the government. Bentham explained the utilitarian theory in respect to a community by defining what the interest of a community connotes. He states that community is a fictitious body, composed of individuals who constitute members; therefore the interest of a community is the total of the interests of the several members who compose it. ${ }^{14}$

Consequently, a discussion of the interest of the community is impossible without that of its members, which leads to the question: what is an individual's interest? Bentham defines an individual's interest as a thing which tends to add to the sum of a person's pleasure or diminish the person's pains. ${ }^{15}$ Therefore, in resource management, government is required to calculate communal interest based on the interests of the greater number of its citizens.

Concerning actions in general, Bentham says no other factor draws an observer's attention as the tendency of its result, that is, the possibility of it resulting in happiness. The tendency in any act is what he terms "utility". ${ }^{16} \mathrm{He}$ argues that utility is the test of all virtue and the obligation to promote general happiness is principal and inclusive of all other virtues. Bentham does not recognize the natural law idea of rights but submits that the principles of justice are embedded in utility and the greatest happiness of the greatest number as directed by state legislation. ${ }^{17}$ Hence if the greatest number of the populace is happy with how the government manages resources, the government has done justice in accordance with the utilitarian theory regardless of how the unhappy-minority feels.

The utilitarian theory posits that human beings are social beings and their major desire is to be happy and avoid pain and that the

12 John Stuart Mill, Utilitarianism (7th edn, Frasers Publications 2004).

13 Jeremy Bentham, The Utilitarians (New York: Dolphin Books 1789) 18.

14 Ibid.

15 Ibid.

16 Bentham, A Fragment on Government (London: Mews-Gate 1776) 4.

17 Jeremey Bentham, An Introduction to the Principles of Morals and Legislation (Oxford: Clarendon Press 1789). 
happiness of people includes their relationship with others, which requires state regulation through legislation. ${ }^{18}$ Bentham relates this to the contract between the government and its citizenry. Impliedly, a contract was made when the people agreed to obey the government, and the government in return promised to govern the people in a manner that promotes their happiness. Bentham went on to question people's justification for disobedience to the government on the ground that the government broke its promise by taking actions contrary to the happiness of the people. ${ }^{19}$ Consequently, the measurement of the state's action should be based on happiness and not laid-down principles. Therefore, government and its agencies should be judged by the consequences of their action on the happiness of the people and not by adherence to some theories of natural law. ${ }^{20}$

What then makes a man happy, both as an individual and as a community of people? Kelsen believes the yearning for justice is man's eternal longing of happiness. It cannot be achieved individually but can be sought as a societal group. ${ }^{21}$ Bentham's moral philosophy is based on two assumptions: the goodness or badness of an act is quantifiable, and the resultant quantities can be added across people. ${ }^{22}$ When the goodness of governmental action is summed up and results in the happiness of the majority of the citizens, then the government can be said to have done justice. Bentham pays no attention to the unhappiness of the minority, the consequence of government's action on the unhappy minority, the sustainability of the happiness of the greater number of the citizens and how the source of the happiness of the majority should not be the source of the unhappiness of others. Utility, according to Bentham, is the tendency of an action or object to

18 M.K. Vyas, "Concept of Justice, Utilitarianism and other Modern Approaches" (2006) < http://www.bhu.ac.in/lawfaculty/blj2006-072008-09/BLJ_2006/ 6_MKVyas.doc. $>$ accessed 3 December 2017.

19 Ibid 7.

20 M.K. Vyas, "Concept of Justice, Utilitarianism and other Modern Approaches" (2006) < http://www.bhu.ac.in/lawfaculty/blj2006-072008-09/BLJ_2006/ 6_MKVyas.doc. $>$ accessed 3 December 2017.

21 Hans Kelsen, Pure Theory of Law (University of California Press 1967) 2.

22 Daniel Read, "Utility Theory from Jeremy Bentham to Daniel Kahneman" (2004) Department of Operational Research, London School of Economics Working Paper No LSEOR 04-64. See Bentham J., Rationale of Reward (William Tait 1843) Chapter 1; John Stuart Mill, Utilitarianism Edited with an introduction by Roger Crisp (Oxford University Press 1998); Walter Sinnot-Armstrong, "Consequentialism" (2011) Stanford Encyclopaedia of Philosophy (2nd Edition), 1. 
cause happiness or otherwise and not the choices we make. ${ }^{23}$ That is, a person's choice of action is not the same as the tendency of action causing happiness. Thus, there is a difference between what an individual ought to do and what he wants to do. For instance, a diabetic patient may choose to take water (what he ought to have) over soda (an alternative that may have given more satisfaction). The idea of hedonism in classic utilitarianism states that a simple game is as good as poetry if the game creates as much pleasure. ${ }^{24}$ The utilitarian theorists base the choice of actions on the resultant happiness or pleasure, but other factors influence actions, particularly government decisions in resource management. Environmental sustainability and respect for fundamental human rights are factors that influence governmental decision-making processes in resource governance, and the utilitarian theory ignores these pertinent factors. Consequences of actions and happiness of the majority are not sufficient determinant factors in resource governance.

\section{APPLICATION OF THE UTILITARIAN CALCULUS TO NIGERIA'S OIL AND GAS MANAGEMENT}

\subsection{Background}

To relate the utilitarian theory to Nigeria's oil and gas management, a brief highlight of Nigeria's demographics is apt. Nigeria is a country with a population of approximately 183 million people and a land mass of $923,768 \mathrm{~km}^{2}$ in which land comprises $910,768 \mathrm{~km}^{2}$ and water accounts for $13,000 \mathrm{~km}^{2} .{ }^{25,26}$ Nigeria is the highest producer of oil in Africa and the sixth largest oil producing country in the world. ${ }^{27}$ The Niger Delta region, from where the oil revenue is derived, is only about $70,000 \mathrm{~km}^{2}$ with a population of about 30 million people, accounting for 23 per cent of Nigeria's population. The Niger Delta is an area in Nigeria that comprises of wetlands and dry lands, covering about

23 Ibid.

24 Jeremy Bentham, Rationale of Reward (William Tait 1843) Chapter 1.

25 Federal Government of Nigeria, "The Federal Republic of Nigeria" (2017) Government Website < https://statehouse.gov.ng/> accessed 27 October 2017.

26 Nigeria National Population Commission, "Nigeria's Population Now" < http:// population.gov.ng/> accessed 27 October 2017.

27 Nigeria National Petroleum Corporation, "Oil Production" < http:// nnpcgroup.com/> (2017) accessed 27 October 2017. 
$75,000 \mathrm{~km}^{2},{ }^{28}$ which makes up about 7.5 per cent of Nigeria's land mass. The term "Niger Delta" refers to the oil-producing region of Nigeria, which includes Bayelsa, Delta, Rivers, Abia, Akwa Ibom, Cross River, Edo, Imo and Ondo States, that is, nine out of the total 36 states and federal capital territory in Nigeria. ${ }^{29}$ The Niger Delta is an oil-rich region dominated by rural communities whose primary occupations are farming and fishing and whose secondary occupations are textile weaving and boat-carving. ${ }^{30}$

Despite the importance of Niger Delta oil wealth to Nigeria's economy, the revenue sharing formula remains debatable. The Federal Account Allocation Committee (FAAC) is responsible for sharing revenues among the three tiers of government in Nigeria - federal, state and local governments. The current revenue sharing formula is federal government - 52.68 per cent; states (collectively) - 26.72 per cent; local governments (collectively) - 20.60 per cent; while 13 per cent derivation revenue goes to the oil-producing states. ${ }^{31}$ This includes the additional revenue given to oil-producing states as members of the Niger Delta region. The major share of the revenue is managed by the Federal Government on behalf of the entire country while the Niger Delta communities remain underdeveloped. Though the greater number of Nigerians enjoys the benefits of oil production, the Niger Delta communities are directly affected by the unsustainable oil production mechanisms. While oil production is a source of significant revenue for many resource-rich countries, it also engenders serious human rights violations; ${ }^{32}$ and Nigeria is an example of a resource-rich country with

28 United Nations Development Programme, "Niger Delta Human Development Report" < http://hdr.undp.org/sites/default/files/nigeria_hdr_report.pdf.> accessed 15 November 2017.

29 Patrick Oviasuyi \& Jim Uwadiae, "The Dilemma of Niger-Delta Region as Oil Producing States of Nigeria" [2010] 16 J of Peace, Conflict and Development 110.

30 Etiosa Uyigue \& Matthew Agho, "Coping with Climate Change and Environmental Degradation in the Niger Delta of Southern Nigeria" (2007) <http:// priceofoil.org/content/uploads/2007/06/07.06.11\%20-\%20Climate_ Niger_Delta.pdf $>$ accessed 1 March 2018.

31 Richard Amaechi Onuigbo, "State Governors and Revenue Allocation Formula in Nigeria: A Case of the Fourth Republic" [2015] 2:7 Intl J of Accounting Research 14.

32 Jan Eliasson, "Natural Resource Wealth Fails to Translate into Equivalent Benefits for People, Fuelling Conflict, Instability" (19 June 2013) United Nations Security Council SC/11037; David Fig, "Natural Resource Extraction and Human RightsBased Abuses in Africa" (2008) 4 Southern Africa Resource Watch 1. 
a record of human rights violations perpetrated in the host communities. ${ }^{33}$

Oil was first discovered in commercial quantities by Shell BP in the Ijaw community of Oloibiri in 1956, in the Ogbia Local Government Area of Bayelsa State. ${ }^{34}$ Since then, the Nigerian government and oil companies have continually engaged in oil production at the expense of local communities. The discovery and production of oil are not limited to Bayelsa State but has spread to the other Niger Delta States. As much as US $\$ 27,788$ million out of Nigeria's total export of US $\$ 34,704$ million in 2016 was derived from oil exportation. ${ }^{35}$ Nigeria derives 95 per cent of export earnings from oil and 70 per cent of government revenue is from the oil sector. ${ }^{36}$ While the discovery of oil in Nigeria seems lucrative to the Nigerian government, it is the major cause of human rights violations in the Niger Delta. Before the discovery of oil, the economy of Nigeria relied greatly on agriculture. ${ }^{37}$ The Nigerian government gradually shifted its attention away from agriculture and other sources of national income to oil production. The agriculture sector, which contributed 64.1 per cent to Nigeria's Gross Domestic Product (GDP) in the 1960 s dropped to 39.10 per cent by $2017 .{ }^{38}$ Other than petroleum, Nigeria has vast reserves of other natural resources, which include tin, iron ore, coal, limestone, niobium, lead, zinc and arable land but none of these generates income at the same rate as petroleum; hence the government is less interested in investing in these resources.

33 Kiikpoye K. Aaron, "Human Rights Violation and Environmental Degradation in the Niger Delta" in: Porter, E. and Offord, B., Eds., Activating Human Rights, (Oxford 2006) 193-215; Kiikpoye K. Aaron, "Perspective: Big Oil, Rural Poverty, and Environmental Degradation in the Niger Delta Region of Nigeria" [2005] 11:2 J Agric Saf Health 127.

34 Patrick Oviasuyi \& Jim Uwadiae, "The Dilemma of Niger Delta Region as Oil Producing States of Nigeria" [2010] J of Peace, Conflict and Development 110.

35 Organization of the Petroleum Exporting Countries (OPEC), "Nigeria" Annual Statistical Bulletin 2017.

36 Nigeria Ministry of Budget and National Planning, "Nigeria's Oil Sector Contribution to GDP Lowest in OPEC" (2017) National Planning Commission Information Unit.

37 Nseabasi Akpan, "From Agriculture to Petroleum Oil Production: What Has Changed about Nigeria's Rural Development" [2012] 1:2 Intl. J. of Developing Societies 97.

38 Nigeria National Bureau of Statistics, "Key Statistics: GDP" (2017) Second Quarter Report. 
Since the 1960s, the Niger Delta peoples have been the direct recipient of the adverse effect of oil production in their region. They have suffered from the effects of oil spills, which occur both on land and offshore. ${ }^{39}$ Oil spills on land affect soil quality, thereby rendering the soil unproductive for farmers while oil spills in water damage the fisheries and render the water undrinkable. Hundreds of oil spills are recorded annually in the Niger Delta, ${ }^{40}$ which results in human inefficiency and outdated pipelines. Apart from oil spills, gas flaring is another issue that threatens the environmental sustainability of the Niger Delta. Nigeria was ranked as the seventh-largest in gas flaring across the world in year 2017, ${ }^{41}$ which was its best ranking since the past decade. Nigeria's ranking was worse in the previous years: fourthlargest in 2012; ${ }^{42}$ second largest in 2007; and highest in 2004. ${ }^{43}$ Nigeria has joined several countries that work on reducing their gas flaring, with about 18 per cent reduction recorded so far. ${ }^{44}$ Oil companies continuously burn associated gas, which is environmentally damaging and dangerous to human health. Experts and members of the affected communities claim that gas flaring causes acid rain and black soot which endanger the lives of people in the region as well as animal and plant life. Aside from the noise and discomfort that gas flaring causes, the combustion is often incomplete, thereby resulting in oil droplets on water, crops, houses and humans. ${ }^{45}$ Despite the development of

39 Jerome Nriagu, et al, "Health Risks Associated with Oil Pollution in the Niger Delta, Nigeria" [2016] 13:3 Intl J Environ Res Public Health 346; Amnesty International, "Nigeria: Hundreds of Oil Spills Continue to Blight Niger Delta" (19 March 2015).

40 Amnesty International, "Decode Oil Spills: Make Oil Companies Accountable for Devastating Oil Pollution in Nigeria" (2017) < https://decoders.amnesty. org/projects/decode-oil-spills > accessed 12 November 2017.

41 The World Bank, "Nigeria's Flaring Reduction Target: 2020" (2017) World Bank Group Report.

42 The World Bank, "World Bank Sees Warning Sign in Gas Flaring Increase" (July 3, 2012) Press Release.

43 The World Bank, "A Twelve Year Record of National and Global Gas Flaring Volumes Estimated Using Satellite Data" (May 30, 2007) Final Report to the World Bank.

44 The World Bank, "New Data Reveals Uptick in Global Gas Flaring" (December 12, 2016) Press Release.

45 UNEP, "Environmental Assessment of Ogoniland Report" Chapter 2 (2011) $\mathrm{DEP} / 1337 / \mathrm{GE}$. 
legislation that addresses gas flaring in Nigeria, ${ }^{46}$ oil companies still incessantly carry out these activities. Clearly, the penal consequence of gas flaring under the relevant legislation has not produced the desired result of stopping oil companies from engaging in this unlawful act nor has it propelled the government to take practical and effective actions to curb the unlawful practice in Nigeria. ${ }^{47}$ Bentham does not recognize the natural law idea of rights but submits that the principles of justice are embedded in utility and the greatest happiness of the greatest number as directed by state legislation. ${ }^{48}$ Therefore, the measurement of the state's action should be based on happiness and not laid-down principles. Government and its agencies should be judged by the consequences of their action on the happiness of the greatest number of people and not by adherence to some theories of natural law. ${ }^{49}$ In this light, the fact that only the minority Niger Delta communities suffer the direct consequences of unsustainable oil production in Nigeria cannot justify the actions of the Nigerian government and oil companies. The long-term effect of oil spills and gas flaring is worrisome; hence the need for pragmatic governmental intervention cannot be overemphasized. The government and the oil companies have not adequately addressed the consequent health problems and social and economic underdevelopment besetting the Niger Delta communities due to oil production despite the unrelenting agitations of the Niger Delta communities. It is paradoxical that the Niger Delta, with its abundance of natural resources, battles significant poverty, environmental degradation and social underdevelopment; thereby making Nigeria's utilitarian-resource management ineffective in protecting the rights of the Niger Delta peoples.

\subsection{Limitations of the Utilitarian Calculus in Nigeria}

The utilitarian calculus, also known as "felicific calculus", is used to

46 Associated Gas Reinjection Act, Laws of the Federal Republic of Nigeria, 2004 Cap A25.

47 Uchenna Jerome Orji, "An Appraisal of the Legal Frameworks for the Control of Environmental Pollution in Nigeria" [2012] 38:2 Commonwealth Law Bulletin 321.

48 Jeremey Bentham, An Introduction to the Principles of Morals and Legislation (Oxford: Clarendon Press 1789).

49 M.K. Vyas, "Concept of Justice, Utilitarianism and other Modern Approaches" (2006) < http://www.bhu.ac.in/lawfaculty/blj2006-072008-09/BLJ_2006/ 6_MKVyas.doc.> accessed 3 December 2017. 
measure the total amount of pain or pleasure caused by an action to determine the best course of action to take. ${ }^{50}$ Bentham states that the calculation of total pain and pleasure must be in relation to identified factors such as duration - how long the pleasure or pain will last; remoteness - how distant the pain or pleasure is; purity - how free from pain the action is; richness - probability of the action leading to other forms of pleasure or pain; intensity - the extent of the pleasure's strength. Others are a certainty - how probable it is that the action will result in pleasure; and extent - the number of people that will experience pleasure. ${ }^{51}$ The utilitarian calculus is explored in relation to Nigeria's resource governance. ${ }^{52}$

Concerning the duration of the pain or pleasure of oil production in Nigeria, the effects of unsustainable oil production in the Niger Delta will persist until effective steps are taken to enforce sustainability. The damage to the ecosystem cannot be addressed overnight. A study was documented on the damage caused by oil spills to the coastal and tidal habitats in Panama over a period of 15 years. One of the researchers stated that what he learned was "never, ever ... allow oil to get into a complex coastal system of mangroves, sea grasses and coral reefs because you'll never get it out." 53 The distress of the Niger Delta people can only be imagined bearing in mind that oil spills and gas flaring are continuous occurrences in the Niger Delta. Besides the effect of the activities of oil companies on humans, its effect on the ecosystem is immense. Oil spills have adverse effects on marine life. Sea creatures barely survive, and the few survivals are contaminated, causing an adverse effect on humans when consumed. ${ }^{54}$ Oil poisoning of marine

50 Jeremy Bentham, The Utilitarians (New York: Dolphin Books 1789) 18.

51 Ibid.

52 For a comprehensive explanation of the utilitarian calculus, see Antoinette Baujard, "A Return to Bentham's Felicific Calculus: From Moral Welfarism to Technical Non-Welfarism" [2009] 16:3 The European Journal of the History of Economic Thought 431; Wesley C. Mitchell, "Bentham's Utilitarian Calculus" [1918] 33:2 Political Science Quarterly 161.

53 The Ocean Portal Team, "Gulf Oil Spill" (2010) < http://ocean.si.edu/gulf-oilspill.> accessed 16 December 2017.

54 National Research Council (US) Committee on Oil in the Sea, "5 Biological Effects of Oil Releases" [2003] Inputs, Fates, and Effects Washington (DC): National Academies Press (US); Collins N. C. Ugochukwu \& Dr. Jürgen Ertel, "Negative Impacts of Oil Exploration on Biodiversity Management in the Niger De Area of Nigeria' [2012] 26:2 Impact Assessment and Project Appraisal 139. 
animals results in food poisoning and loss of lives. This also results in loss of means of income because most Niger Delta community members, as fishermen and farmers, rely on the environment for their sustenance. ${ }^{55}$ This long-term pain cannot be compared to the longterm gratification the government, oil companies and the Nigerian people currently enjoy from oil production. The revenue from oil production has been a major source of income for the Nigerian government for a long while and will likely continue to be a significant source of income for all the levels of government. Though the "duration" of the pleasure of oil production in Nigeria is long, so also is the pain to the Niger Delta communities.

With regards to the remoteness of pain or pleasure, the effect of oil spills, gas flaring and damaged ecosystem is close to the Niger Delta communities but not to the Federal Government whose official site is in Abuja, or other communities far removed from the local realities of oil production. When discussing Bentham's thesis on the remoteness of pain and pleasure in relation to Nigeria's oil production, due consideration should be given to the welfare of the minority communities whose ancestral homes are destroyed, whose habitations are forcefully taken over by the government, whose life expectancy rate keeps dwindling due to the adverse effect of oil pollution and, most importantly, whose family and loved ones are killed when government imposes military actions. ${ }^{56}$ By no stretch of imagination can this be linked to other Nigerians living in other regions who do not understand what it means to live in the Niger Delta region. Though the consequence of oil production is remote to the government and non-Niger Delta regions, this is not a justification for ignoring the human rights violations perpetrated in the minority-Niger Delta communities.

There is no doubt that oil production in Nigeria is not free from pain but the level of pain is disproportional. Though all regions in Nigeria benefit from oil revenue, the Niger Delta communities bear the

55 Oyebamiji M. Adekola \& Mba C. Igwe, "Effects of Oil Spillage on Community Development in the Niger Delta Region: Implications for the Eradication of Poverty and Hunger (Millennium Development Goal One) in Nigeria" [2014] 1:1 World Journal of Social Science 27.

56 Amnesty International, "Nigeria: Petroleum, Pollution and Poverty in the Niger Delta" (2009) AFR 44/017/2009;; Tambari Ogbonanwii Dick, "Oil Politics and its Social Implications in the Niger Delta: A Study of Obari Gomba's Pearls of the Mangrove" [2016] 10:3 African Research Review 183. 
direct consequence of oil production within their communities. In comparison to the benefit the government, non-oil producing states in Nigeria and oil companies derive from oil production, the resultant pain is negligible, but this is not the plight of the Niger Delta peoples who are daily saddled with the consequences of oil production with minimal positive consequence on their communities. Therefore the purity of oil production in Nigeria is high for the government, other regions and oil companies but low for the host communities.

Bentham refers to the richness of action as the "fecundity" of an action or the chance it has of being followed by sensations of the same kind: that is, pleasures, if it be a pleasure: pains, if it be a pain. ${ }^{57}$ The pain of oil production has already been discussed earlier in this article, but the probability of it leading to other forms of pain based on the political and economic terrain of Nigeria is high. Due to the dissatisfaction of Niger Delta youths, militancy ${ }^{58}$ and pipeline vandalism $^{59}$ have become prevalent in this region. The consequential pains of militancy, pipeline vandalism and youth unemployment in the Niger Delta are a threat to national security, a hindrance to sustainable and stable power supply in Nigeria, environmental degradation, damage to Nigeria's international image and loss of lives. ${ }^{60}$

57 Jeremy Bentham, The Utilitarians (New York: Dolphin Books 1789) 37.

58 Iro Aghedo, "Winning the War, Losing the Peace: Amnesty and the Challenges of Post-Conflict Peace-Building in the Niger Delta, Nigeria" [2013] 48:3 Journal of Asian and African Studies 267; Surulola James Eke, "Running to Fight Another Day: Commodification of Peace and the Resurgence of Violence in Post-Amnesty Niger Delta" [2016] 9:2 Journal of African Security 136.

59 In 1995, 7 cases of vandalism were reported, in 1996 - 33 cases; in 1997 - 34 cases, in 1998 - 57 cases, and in 1999 - 497 cases. The situation has worsened in recent times. Between 2010 and 2012, the total reported cases of vandalism on pipelines belonging to the Nigerian National Petroleum Corporation were 2,787 resulting in a loss of $157.81 \mathrm{mt}$ of petroleum products worth about 12.53 billion Naira and in 2015, 2,832 cases of pipeline vandalism were reported. Okoli Al Chukwuma \& Orinya Sunday, “Oil Pipeline Vandalism and Nigeria's National Security" [2013] 13:5 Global J of Human Social Science 66; Iro Aghedo, "Winning the War, Losing the Peace: Amnesty and the Challenges of PostConflict Peace-Building in the Niger Delta, Nigeria" [2013] 48:3 Journal of Asian and African Studies 267; Surulola James Eke, "Running to Fight Another Day: Commodification of Peace and the Resurgence of Violence in Post-Amnesty Niger Delta" [2016] 9:2 Journal of African Security 136; Alphonsus Njoku, "Oil Pipeline Vandalism and Its Effects on the Socio-Economic Development in Nigeria Society" [2016] 4:4 Int'l J of Multidisciplinary Academic Research 47.

60 Alphonsus Njoku, "Oil Pipeline Vandalism and Its Effects on the Socio-Economic Development in Nigeria Society" [2016] 4:4 Int'l J of Multidisciplinary Academic Research 47. 
Besides, the probability of the pleasure of oil production leading to other forms of pleasure is high, but the intensity of the pleasure ("the extent of the pleasure's strength") depends on the economic sector people engage with. As the highest paid expatriate workers in Africa and 11th highest paid in the world, expatriate workers in Nigeria's oil and gas sector derive much pleasure in oil and gas production. ${ }^{61}$ With over 70 per cent of government revenue coming from the oil sector and 95 per cent of export earnings from oil, ${ }^{62}$ the intensity of the Nigerian government's pleasure in oil production is relatively high. Politicians and oil sector officials also benefit from oil production, but the extent of their pleasure cannot be ascertained because their income and loot are not revealed to the public. ${ }^{63}$ Considering the high intensity of the pleasure derived from oil production by the government, politicians ${ }^{64}$ and oil companies with minimal direct "pain", their actions can be justified under the utilitarian theory as having a high intensity of pleasure.

61 Michael Eboh, "Nigeria's Expatriate Oil Workers Highest Paid in Africa" The Vanguard (Lagos, 12 February 2013).

62 United Nations Development Programme, "Niger Delta Human Development Report" < http://hdr.undp.org/sites/default/files/nigeria_hdr_report.pdf.> accessed 15 November 2017.

63 See Dareen Kew \& David L. Phillips, "Seeking Peace in the Niger Delta: Oil, Natural Gas, and Other Vital Resources" [2013] 24:1 New England Journal of Public Policy 1. There have been reports of corruption in the Nigerian oil sector. Human Rights Watch, "Chop Fine: The Human Rights Impact of Local Government Corruption and Mismanagement in Rivers State, Nigeria" [2007] New York, Human Rights Watch; Alexandra Gillies, "Reforming Corruption Out of Nigerian Oil? Part Two: Progress and Prospects" (2009) U4 Brief: Anticorruption Resource Center 4. After Nigeria implemented the Extractive Industries Transparency Initiative, the government undertook a comprehensive audit of the oil sector and recovered unpaid incomes of US\$9.8billon from 1999-2008. After the initial audit, not less than US\$2.4billion of lost revenue was retrieved. The World Bank, "Combating Corruption; Nigeria" (2017) Understanding Poverty Governance Report. An estimate of US\$380billion of oil revenue is reported to have been wasted or stolen by officials in the oil and gas sector over four decades. Natural Resource Governance Institute, "Country Strategy Note: Nigeria" [August 2016] NRGI Report.

64 For example, in the 2017 budget, N1.6 billion was allocated for the President's office and N448.6million for the Vice-President's office. Seun Opejobi, "2017 Budget: Money Buhari Allocated for his Kitchen will Pay Salaries of 10,000 Nigerians - Ben Bruce" Daily Post (Lagos, 7 February 2017). 
The probability of oil production resulting in pleasure is certain because it is a major source of revenue for the country. However, this utilitarian calculus factor fails to consider the probability of the action resulting in pleasure for the person bearing the pain. In the Nigerian context, the probability of oil production leading to the pleasure of the Niger Delta people is quite low when compared to the resultant pain while the probability of oil production leading to the pleasure of other Nigerians, government and oil companies is very high. Nigeria, as a whole, enjoys the benefit of oil production. This implies that the minority Niger Delta communities bear the resultant consequence of oil production, which benefits all the states of Nigeria, the oil companies and the Nigerian government. The utilitarian theory posits that an action can be justified by the number of people that will benefit from it. This position does not take into cognizance the proportion of the people who suffered the resultant pain of the action that caused pleasure to the other larger number of people, and this is a major ground for faulting the utilitarian theory. This implies that the utilitarian theory justifies the adverse effect of oil production on the Niger Delta communities because they are only about 23 per cent of the total population of Nigeria. Adequate consideration should be given to the minority communities that suffer the consequence of actions that tend to benefit the larger groups. Minority communities should not be made to sacrifice their happiness and well-being for the benefit of the other communities.

\subsection{Shortcomings of Applying the Utilitarian Theory to Nigeria's Resource Management}

\subsubsection{Impracticability of Action Comparison}

The flaws of the utilitarian calculus are evident with regards to its applicability to Nigeria's oil and gas management. The utilitarian calculus requires the measurement of benefits or harms resulting from action in comparison to the result of other actions. The practicability of this requirement is almost impossible. One can only compare the consequence of two actions where there has been an experience of both actions. Simply guessing cannot give a definite confirmation of the consequence of an action. Nigeria has concentrated on oil production since it was discovered in the 1950s and has relied on income generated from oil production since this time. Utilitarianism can be interpreted in this instance to suggest that Nigeria should stop oil production for a 
while in order to compare the consequence to active oil production (as it is now). This shows that the idea of comparing consequences is impossible because the Nigerian government cannot stop production in order to compare the consequences of oil production or nonproduction. Matters of such economic magnitude cannot be left to the experimentation of the utilitarian theorists. Also, comparison of the consequences of actions cannot be justified in certain instances. It is clear that the consequences of oil production in Nigeria affect the Niger Delta people and their lives are continuously affected in the process. The utilitarian theory cannot be a justification for the economic advantage of oil production in Nigeria, which has resulted in the loss of lives and deteriorating health of the host community members. Comparison of the value placed on life cannot be parallel to any other although the value placed on life, human dignity, health and environment depends on the moral values the agent in question has imbibed over time and how far human rights standards are enmeshed in resource governance.

\subsubsection{Inability to Ascertain Consequences of Actions}

Ability to ascertain the consequences of an action is also paramount in justifying the rightness or wrongness of such action based on the utilitarian theory. Considering the historical antecedent of Nigeria, one can decipher the innocent intentions of the then leaders of the country regarding oil production. The northern and southern protectorates of Nigeria were amalgamated in 1914 by the colonial government. A few decades later, prominent Nigerians (from both the North and the South) clamoured for a federal constitution for all the regions to have autonomy. In 1954, their request was granted at the London conference and the first Nigerian Federal Constitution (the Lyttleton Constitution), which gave the regions autonomy, emerged. This was the Constitution in force as at the time oil was discovered in Nigeria. ${ }^{65}$ This implies that the Southern "half" of what is now Nigeria was in charge of oil production at the time and not the central or federal government. The subsequent regimes derailed from the intentions of the government that welcomed oil production in Nigeria by ignoring other economic sectors of the country. In 1960, crude oil production contributed 0.30

65 Helen Chapin Metz, Nigeria: A Country Study (Washington: GPO for the Library of Congress, 1991). 
per cent of Nigeria's total GDP. In 1970, oil contribution rose to 7.10 per cent and further climbed to 22 per cent in 1980. In 1990 it decelerated to 12.80 per cent before rising significantly to 47.5 per cent in 2000. By 2002, it declined again relative to the previous period but remained significant in magnitude at 40.6 per cent. ${ }^{66}$ Crude oil and natural gas contributed to the nominal GDP of 40.86 per cent and 32.43 per cent in 2011 and 2013 respectively. ${ }^{67}$ This shows how the trends have changed over time and the rapid derailment from other sectors to oil production. The initial plan of the government was to have oil production as a supportive source of revenue in addition to the other existing sources. Nigerian leaders have changed over time, and the country has welcomed a set of political leaders with different aspirations. This shows that the consequence of action at the time of acting is never certain. The Nigerian government in the late 1950s and early 1960s could not have imagined that their act of welcoming oil companies into the country to explore natural resources could result in the consequences being experienced today. The justifiability of the government's action in the late 1950s and 1960s cannot be founded on the consequences of today. The desired consequence has been intercepted by the emergence of leaders with different intentions and focus which makes the utilitarian theory unreliable in this instance.

\subsubsection{Failure to Recognize Considerations of Justice}

The utilitarian theory is ineffective for failing to recognize considerations of justice. This criticism is revealed where an unjust course of action produces a great benefit to society as a whole. ${ }^{68}$ Moral values come to bear when there is a need to make decisions that may seem advantageous to the decision maker and the majority but harmful to the minority. With regards to oil and gas management in Nigeria, utilitarianism is not an effective and just principle guiding government

66 Bolawa Fadojutimi, "Crude Oil in Nigeria; a Blessing or a Curse" (2012) < http:/ /www.slideshare.net/bolawafadoju/discovery-of-crude-oil-in-nigeria-ablessing-or-a-curse.> accessed 10 October 2017.

67 National Planning Committee, "Nigeria's Oil Sector Contribution to GDP Lowest in OPEC-Blueprint" (2014) < http://www.nationalplanning.gov.ng/2017/> accessed 19 December 2017.

68 Manuel Velasquez et al "Calculating Consequences: The Utilitarian Approach to Ethics" < http://www.scu.edu/ethics/practicing/decision/calculating.html.> accessed 12 December 2017. 
decisions. The manner of oil production in Nigeria is unjust to the host communities and advantageous to the government, oil companies and some in the larger population. The moral values of the government and oil companies ought to compel them to take actions to alleviate the adverse effects of oil production on the Niger Delta communities. Therefore, the utilitarian calculus cannot account for human rights and what rights should protect individuals from the operation of utilitarianism in its aggregate form. ${ }^{69}$

\subsubsection{Failure to Identify Circle of Influence}

In calculating the benefits and harms of individual actions to other people, utilitarianism requires that a person should look beyond selfinterest and consider impartially the interests of all persons affected by the actions. According to John Stuart Mill, "the happiness which forms the utilitarian standard of what is right in conduct, is not... (one's) own happiness, but that of all concerned. As between his own happiness and that of others, utilitarianism requires him to be as strictly impartial as a disinterested and benevolent spectator." ${ }^{\prime 0}$ He stated further that:

Human beings are also motivated by such internal sanctions as self-esteem, guilt, and conscience. Because we all have social feelings on behalf of others, the unselfish wish for the good of all is often enough to move us to act morally. Even if others do not blame or punish me for doing wrong, I am likely to blame myself, and that bad feeling is another of the consequent pains that I reasonably consider when deciding what to do. ${ }^{71}$

This statement shows that the utilitarians also acknowledge the place of morality in reaching a just decision because the "internal sanctions" relied on by Mill can only be quickened by moral values. Human beings naturally protect their self-interest, so considering the interest of others requires an inner conviction to do so which is the place of morality. Another challenge with the utilitarian theory is how to ascertain those the agent must include in his consideration. Is he

69 Ernest J. Weinrib, “Utilitarianism, Economics, and Legal Theory” [1980] 30:3 The University of Toronto Law J 307.

70 Ibid.

71 Garth Kemerling, "Utilitarianism" (2011) < http://www.philosophypages.com/ hy/5q.htm. > accessed 15 August 2017. 
required to consider his allies or his local communities or his region or his country? Utilitarian theory is silent on how far the circle of people to be considered gets. G.E. Moore analysed this challenge by stating that when the issue of consequences is considered, the question of who is included in the circle must be asked. Is it for those in our own group ("group egoism"), or those in our country ("nationalism"), or those who share our skin colour ("racism"), or all human beings ("humanism or speciesism"), or all sentient beings. ${ }^{72}$ Classical utilitarianism expanded the circle by suggesting that the resultant pain and suffering actions may cause to animals should be considered and not restricted to human beings. ${ }^{73}$

In applying the classical utilitarian theory in the process of ascertaining who to consider in decision making, the Nigerian government is expected to consider the consequences of its actions on all Nigerians, the environment and animals. This argument supports the need to protect marine animals being affected by oil spills in the Niger Delta, but there is no yardstick for the group of human beings to be considered. This can only be determined by the nature of the act in question. An act of significant social, economic and environmental consequences as oil production requires the Nigerian government putting the whole world into consideration because climate change affects the whole world and this is one of the adverse consequences of unsustainable oil production. Conversely, the Niger Delta communities have the responsibility of deciding who to consider when fighting for their right and against oil production in their communities. The Niger Delta communities will most likely put their interest over that of the government or oil companies or other states in the country that benefit from the revenue generated from oil production. In this instance, the utilitarian theory is not effective in deciding what action the Niger Delta communities should take because the morality or otherwise of the peoples' action is not based on who bears the consequences of

72 Lawrence M. Hinman, "Utilitarianism" (2010) University of San Diego, Social Ethics Summer PowerPoint Presentation, <http://www.google.ca/ url? sa $=\mathrm{t} \& \mathrm{rct}=\mathrm{j} \& \mathrm{q}=\& \mathrm{esrc}=\mathrm{s} \&$ source $=$ web $\& \mathrm{~cd}=1 \& \mathrm{cad}=$ rja\&uact $=8 \& \mathrm{ved}=0 \mathrm{a}$ hUKEwjbxcjljMzZAhUH72MKHTXBAigQFggpMAA\&url=http\%3A\%2F $\% 2 \mathrm{Fwww}$.cengage.com $\% 2 \mathrm{Fresource}$ uploads $\% 2 \mathrm{Fdownloads} \% 2 \mathrm{~F} 113$ 3050018_377560.docx\&usg=AOvVaw1P07ty_oRiCcr4oJSrA6y5 $>$ accessed 4 December 2017.

73 Ibid. 
their action but on the struggle to prevent the further violation of their human rights.

\section{HRBA AS AN ALTERNATIVE TO THE INEFFECTIVE UTILITARIAN RESOURCE MANAGEMENT IN NIGERIA}

One of the critics of utilitarian theory is the natural law theorist, Francis Herbert Bradley, who argues that "utilitarianism conflicts with ordinary moral judgments". ${ }^{74}$ This article has established that the Nigerian oil and gas management is significantly utilitarian and has been ineffective in promoting the human rights of the Niger Delta communities. Hence, a progressive and effective alternative is desirable. An alternative to utilitarian theory is the protection, promotion and enforcement of human rights standards in resource governance through the HRBA. In criticizing the utilitarian theory, Dworkin posits that rights protect the interest of human beings by discountenancing the utilitarian's common good approach as a justification for limiting rights. ${ }^{75}$ This position is justified by taking rights seriously and identifying that the utilitarian argument of gains cannot justify the prevention of man from doing what he has the right to do. No one should be debarred from doing what he has the right to do simply because the majority will be adversely affected by his actions. This reveals the conflict between individual interest and communal interest. ${ }^{76}$ Rights are more effective in protecting people's interest unlike the utilitarian common-good approach, which conflicts with human rights standards. A proper law must be consistent with justice, ${ }^{77}$ and the unjust management of resources to the detriment of the Niger Delta peoples cannot be excused because the majority derives happiness from it.

74 Francis Herbert Bradley, Ethical Studies, 2nd edition (Oxford: Clarendon, 1927). See Herbert Lionel Adolphus Hart, Essays in Jurisprudence and Philosophy (United Kingdom: Oxford University Press, 1983); Simon Knutsson, "Measuring Happiness and Suffering" [2017] Foundational Research Institute 1; Jonathan Glover, "Utilitarianism and its Critics" [1990] PhilPapers.

75 Richard H. Pildes, "Why Rights Are Not Trumps: Social Meanings, Expressive Harms, and Constitutionalism" [1998] 27:2 J of Legal Studies 725.

76 Ibid. See Gordon Wood, The Creation of the American Republic (Virginia: Omohundro Institute of Early American History and Culture 1969).

77 Marcus Tullius Cicero, De Re Publica: Selections (Cambridge University Press 1995). 
As a progressive and effective alternative to the utilitarian resource management, the HRBA is proposed as a normative framework that promotes the recognition and protection of fundamental human rights standards in the execution of every project or during decision-making processes. "The HRBA is a United Nations directive, which focuses on those who are most marginalized, excluded or discriminated against". ${ }^{78}$ The HRBA underscores the mainstreaming of human rights standards into governance and the implementation of human rights impact assessment to ensure compliance with human right standards. This implies that procedural and substantive human rights standards are made the foundation of every project, and decision-making process and periodic evaluation of stakeholders' human rights compliance are implemented during project planning and execution. The HRBA to resource management is a normative framework that ensures that the interests and concerns of minorities are identified and addressed by the government and provides avenues to hold the government and third parties accountable for their human rights obligations. ${ }^{79}$ The elements of the HRBA are effective participation, accountability, equality, transparency and empowerment. ${ }^{80}$

The two rationales for the HRBA are the recognition of the moral and legal justification of a rights-based approach and the recognition that the HRBA leads to sustainable development. ${ }^{81}$ Implementation of the HRBA in Nigeria's resource governance implies that recognition and protection of the human rights of every citizen, particularly the host and impacted communities, will be at the core of every decision and action taken by the government and effective policies are in place

78 UNFPA, "Human Rights Based Approach" < http://www.unfpa.org/humanrights-based-approach $>$ accessed 11 September 2017.

79 SIDA, "A Human Rights Based Approach to Environment and Climate Change" (February 2015) < https://www.sida.se/globalassets/sida/eng/partners/ human-rights-based-approach/thematic-briefs/human-rights-based-approachenvironment-climate-change.pdf $>$ accessed 22 February 2018. For more on the implementation of the HRBA, see Victorian Equal Opportunity and Human Rights Commission, From Principle To Practice: Implementing The Human Rights Based Approach In Community Organizations (Superprint Publications 2008).

80 Amanda Loeffen, "Linkages between the Right to Water and the Implementation of IWRM" (November 8, 2016) Waterlex presentation.

81 UNICEF, "Human Rights-based Approach to Programming" (2016) < https:// www.unicef.org/policyanalysis/rights/index_62012.html> accessed 20 February 2018. 
to ensure compliance with human rights standards. Stakeholder participation in resource management is one of the elements of the HRBA and the Niger Delta communities, as the direct recipients of the effect of oil production, are stakeholders and their right to partake in resource management must be respected. ${ }^{82}$ For an effective HRBA to resource management in Nigeria, the government must be committed to disapproving discriminatory practices, promote accountability and transparency in revenue management, continuously commit to empowering the Niger Delta communities and periodically assess government and oil companies' compliance with their human rights obligations. ${ }^{83}$

Several human rights standards apply to oil and gas management and the protection of the rights of the Niger Delta peoples. The International Covenant on Civil and Political Rights (ICCPR) ${ }^{84}$ states that: "every human being has the inherent right to life... and no one shall be arbitrarily deprived of his life". ${ }^{85}$ On the contrary, the right of the Niger Delta peoples to life has been violated severally through unsustainable oil production, environmental pollution, ${ }^{86}$ unjust military actions, ${ }^{87}$ and poor healthcare system. ${ }^{88}$ Additionally, the International

82 Barry Barton, "Underlying Concepts and Theoretical Issues in Public Participation in Resources Development" in Donald Zillman, Alastair Lucas and George Pring Human Rights in Natural Resource Development (Oxford University Press 2002) 81; Robert D. Lamb, Bill Varettoni, \& Chunli Shen, "Participatory Development and the World Bank" [2005] 14:2 International Affairs Review 171.

83 For more on the HRBA, see Damilola Olawuyi, The Human Rights-Based Approach to Carbon Finance (Cambridge University Press, 2016) 1-20; UNFPA, "The Human Rights-Based Approach" (2014) < https://www.unfpa.org/humanrights-based-approach> accessed 20 February 2018; UN Development Group, "HRBA Portal" < http://hrbaportal.org/faq/what-is-a-human-rights-basedapproach $>$ accessed 22 February 2018.

84 Adopted and opened for signature, ratification and accession by General Assembly resolution 2200A (XXI) of 16 December 1966 entry into force 23 March 1976, in accordance with Article 49.

85 Ibid Article 6.

86 For report on the impacts of oil production on Niger Delta communities, see Adati Ayuba Kadafa, "Environmental Impacts of Oil Exploration and Exploitation in the Niger Delta of Nigeria" [2012] 12:3 Global J. of Science Frontier Research Environment \& Earth Sciences 19.

87 For example, the Odi community killings of 1999. See Osita Nwajah, "A Tale of Military Massacres: From Ogoni Land to Odi Town" < http://www.waado.org/ environment/fedgovt nigerdelta/bayelsainvasion/FederalGovernInvades Bayelsa/MilitaryInOdi/MilitaryMassacres.html> accessed 15 August 2017.

88 Zelda Elum, Keletso Mopipi and A. Henry Ukoha, "Oil Exploitation and its Socioeconomic Effects on the Niger Delta Region of Nigeria" [2016] 23:13 Environmental Science and Pollution Research 12880. 
Covenant on Economic, Social and Cultural Rights (ICESCR) ${ }^{89}$ provides that State parties "shall recognize the right of everyone to an adequate standard of living for himself and his family, including adequate food, clothing and housing". ${ }^{90}$ Nigeria as a State party to the ICCPR and ICESCR is obliged to protect the rights of the Niger Delta communities to life and an adequate standard of living, but the actions of the Nigerian government has worked against the realization of these rights. ${ }^{91}$ The environmental degradation caused by unsustainable oil production impedes the agricultural practices of the Niger Delta peoples, thereby depriving them of their means of income and reducing their access to food. ${ }^{92}$ The human rights violations against the Niger Delta peoples cannot be excused because the larger number of the country benefit from oil production. Proper management of resources will not trade justice for the benefits accruing to the majority groups. At the regional level, the African Charter on Human and Peoples' Rights (African Charter) ${ }^{93}$ states that every individual has the right to physical and mental health, promotion and protection of traditional values, equality, economic, social and cultural development with due regard to their freedom and identity and right to general satisfactory environment favourable to development. ${ }^{94}$ Nigeria as a State party domesticated the African Charter through the enactment of the African Charter on Human and Peoples' Rights (Ratification and Enforcement) Act. ${ }^{95}$ This implies that the provisions of the African Charter have the force of law in Nigeria and government officials are required to comply with the dictates of the Charter. ${ }^{96}$ However, the level of

89 U.N. Doc. A/6316, adopted and opened for signature, ratification and accession by General Assembly resolution 2200A (XXI) of 16 December 1966 entry into force 3 January 1976, in accordance with article 27.

90 Article 11(1).

91 See Cyril Obi, "Oil and Conflict in Nigeria's Niger Delta Region: Between the Barrel and the Trigger" [2014] 1:2 The Extractive Industries and Society 147.

92 Chris Opukri \& Ibaba Samuel Ibaba, "Oil Induced Environmental Degradation and Internal Population Displacement in the Nigeria's Niger Delta" [2008] 10:1 J. of Sustainable Development in Africa 173; Mobolaji Aluko, "Sustainable Development, Environmental Degradation and the Entrenchment of Poverty in the Niger Delta of Nigeria" [2004] 15:1 J. Hum. Ecol. 63.

93 CAB/LEG/67/3 rev. 5, 21 I.L.M. 58 (1982).

94 Articles 16, 17, 22, and 24 of the African Charter.

95 Chapter 10 LFN 1990.

96 Ibid Preamble. For the impact of the African Charter on Nigeria's domestic law, see Eghosa Osa Ekhator, "The Impact of the African Charter on Human and Peoples' Rights on Domestic Law: A Case Study of Nigeria" [2015] 41:2 Commonwealth Law Bulletin 253. 
environmental degradation, displacements, infrastructural underdevelopment, and ineffective healthcare system, among other things, deprives the Niger Delta peoples of the realization and enjoyment of their rights. In the case of Social and Economic Rights Action Centre (SERAC) and Another v. Nigeria, ${ }^{97}$ SERAC brought an action against the then Nigeria military government, claiming that the government through its business association with Shell Petroleum Development Corporation (SPDC) exploited oil reserves in the Ogoniland without regard for the health and environmental safety of the Ogoni people. The African Commission on Human and Peoples' Rights (African Commission) found that Nigeria had violated many of the rights protected under the African Charter and appealed to the State party, Nigeria, to stop the attacks on the Ogoni people, undertake investigations into human rights violations, ensure restitution of victims of human rights violations and develop measures to prevent further human rights violations. The African Commission also stated that the Nigerian government has a duty to protect its citizens, including the host communities, from third parties' actions that may interfere with the enjoyment of human rights. ${ }^{98}$

Although the human rights violations connected with oil production are only directly experienced by the minority Niger Delta communities, the utilitarian's common good approach is not a tenable justification for infringing on the rights of the minority host communities for the benefit of the whole country. Some of the identified issues besetting minority groups are a threat to their survival and inequality, ${ }^{99}$ and the Niger Delta communities are not exempted. The utilitarian nature of managing resources has proved to be ineffective, unsustainable and detrimental to the Niger Delta communities. Oil production can be managed sustainably and with justice and fairness for all Nigerians if the Nigerian government and oil companies will imbibe the HRBA into their decision-making processes and ensure that the rights of all Nigerians, particularly the rights of the Niger Delta peoples, are not violated or neglected for the benefit of the government, oil companies or majority of Nigerians. The HRBA to Nigeria's resource management

97 [2001] African Human Right Law Report 60 (Communication 155/96).

98 Ibid para. 57.

99 Office of High Commissioner, United Nations Human Rights, "Minority Rights: International Standards and Guidance for Implementation" (HR Publication, HR/PUB/10/3, 2010). 
is a roadmap to enforcing the human rights of all Nigerians, particularly the Niger Delta communities, and addressing the militancy, vandalism and other consequential challenges currently besetting Nigeria's resource management. The HRBA is an effective framework that guarantees the acquisition of the social license to operate, which is required for the peaceful coexistence of the Niger Delta peoples, project proponents and the government. Through the human right impact assessment threshold, the government and oil companies are obliged to guarantee compliance with fundamental human rights standards and stakeholders are held accountable for their actions. Holding oil companies and government accountable for their decisions and actions in resource management is an effective way of reducing gas emissions, gas flaring, unjust military actions, displacements and environmental degradation. The ripple effects of applying the HRBA to Nigeria's resource management are environmental sustainability, revenue transparency, sustainable resource management and social, economic and infrastructural development of the Niger Delta and Nigeria as a whole.

\section{CONCLUSION}

This article has established that the Nigerian government is substantially utilitarian with regards to its decisions and actions on oil production. Its mode of operation is at variance with international human rights standard, which is a pointer to the ineffectiveness of utilitarian theory in promoting human rights. The promotion and protection of the human rights of the Niger Delta peoples through the HRBA is an effective and progressive alternative to Nigeria's current resource management. The utilitarian mode of governance is obviously not working for a significant group of people who face serious violations of their human rights, hence the need for change.

The rights of Niger Delta peoples should not be sacrificed for the gains of oil production. The incessant conflicts in the Niger Delta region are largely due to the reaction of the host communities to unsustainable oil and gas management and the resultant social and economic underdevelopment. There can be peaceful, productive and sustainable oil and gas management in Nigeria if every decision-making process is instituted on fundamental human rights standards. The government needs to strictly monitor the activities of oil companies and its agencies to ensure that human rights standards are not violated, and projects that could be implemented contrary to human right standards are not 
approved or discontinued. The HRBA to resource management requires the government, oil companies and project proponents to substantiate their compliance with human rights standards and guarantee the protection of the human rights of every citizen. Oil production does not have to be done at the detriment of the Niger Delta peoples. Sustainable oil and gas production can be achieved if the people in government and the oil companies operating in Nigeria are motivated by their inner sanctions which give them an inner conviction of the morality or otherwise of their actions.

This brings to mind Dworkin's suggestion that morality needs to be incorporated into constitutional law. ${ }^{100}$ The "moral reading" proposes that everyone, including lawyers and judges, should interpret and apply political, constitutional provisions "on the understanding that they invoke moral principles about political decency and justice" thereby making political morality the centre of constitutional law. ${ }^{101}$ An initial step of assessing the environmental, economic and social challenges of the Niger Delta by the Nigerian government backed by a commitment to addressing the identified challenges is a pragmatic approach of restituting the human rights violations in the Niger Delta. Maximizing the pleasure of the greatest number has not produced the desired result, and thus defeats the purpose of the utilitarian theory in determining the proper course of action in Nigeria's resource management. Upholding human rights standards in resource management and implementing periodic human rights compliance assessment are progressive pathways to sustainable development. The current environmental and social decadence of the Niger Delta can be addressed if the Nigerian Government and oil companies operating in Nigeria will inculcate the HRBA and value human life, human rights and sustainable development over the economic gains of oil production.

100 Ronald Dworkin, Freedom's Law: The Moral Reading of the American Constitution (Harvard University Press 1996).

101 Ibid. 